\title{
CYCLIC CHANGES IN THE METABOLISM OF GLYCOGEN IN CERVICAL MUCUS OF BONNET MONKEYS (MACACA RADIATA)
}

\author{
A. R. SHETH, G. V. SHAH, B. A. GADGIL AND SHANTA S. RAO \\ Institute for Research in Reproduction (ICMR), \\ Parel, Bombay-400 012, India
}

(Received 9th May 1974)

The bonnet monkey (Macaca radiata) of South India secretes large quantities of cervical mucus (Ovadia, McArthur, Kopito \& Ulfelder, 1971) but little is known about its biochemical composition. Enzymes of cervical mucus have an important rôle to play by providing energy for sperm motility, survival and transport in the female genital tract.

In this study, an attempt was made to evaluate cyclical changes in the activities of glycogen phosphorylase, maltase and amylase, enzymes involved in the degradation of glycogen, and to compare these changes with alterations in serum LH levels during the menstrual cycle.

Adult female bonnet monkeys were housed individually in open wire cages. Upon arrival from dealers, the animals were examined, weighed (weights ranged between 2 and $4 \mathrm{~kg}$ ), placed in quarantine, tested for tuberculosis and kept under close observation for a period of 3 months before use in this study. The animals were fed with Hindustan Lever monkey chow and were maintained in a room at 24 to $26^{\circ} \mathrm{C}$.

Cervical mucus and blood samples were taken from four monkeys on alternate days throughout the menstrual cycle, starting on Day 7 after the onset of menstruation. Gervical mucus was aspirated into a glass tube and weighed. Maximal secretion of mucus was observed between Days 10 and 14 .

Amylase activity was determined by the method described by Bernfield (1955). The enzyme activity was expressed in terms of $\mathrm{mg}$ maltose liberated $/ \mathrm{hr} / \mathrm{g}$ of mucus. Samples of cervical mucus were analysed for maltase activity by the procedure described by Sheth, Gunaga \& Rao (1970). Glycogen phosphorylase activity was determined by the method of Demers, Gabbe, Villee \& Greep (1972) which measures the incorporation of $\left[{ }^{14} \mathrm{C}\right]$ glucose-1-phosphate into glycogen.

Serum LH levels were measured by radioimmunoassay using the classical double-antibody method. The antiserum to ovine LH employed for the assay was examined for any cross-reactivity it might have with other protein hormones, but was found to be specific for LH. The standard reference preparation used was NIH-OLH-S18 by NIAMD, NIH, U.S.A. Highly purified ovine LH was iodinated using ${ }^{125} \mathrm{I}$ according to the procedure described by Greenwood, Hunter \& Glover (1963) and modified by Midgley (1966). To avoid interassay 
variations, all the samples obtained during the cycle were analysed in a single assay. All the determinations were carried out in duplicate.

Glycogen phosphorylase activity was low during the early follicular phase, increased as the cycle progressed till just before the LH level reached a peak value and thereafter declined during the luteal phase of the cycle (Text-fig. 1).

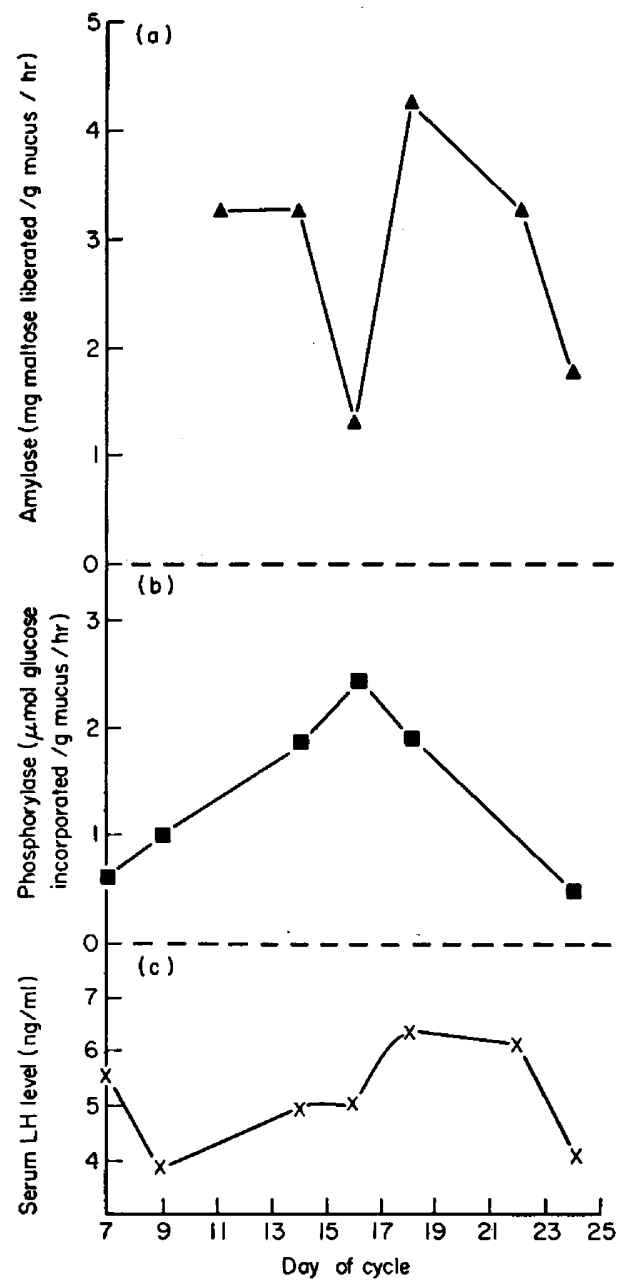

TexT-Fig. 1. The pattern of the cyclical changes observed in (a) amylase activity, (b) glycogen phosphorylase activity, and (c) serum LH levels in the cervical mucus of a bonnet monkey during the menstrual cycle from Day 7 after the onset of menstruation to Day 25.

Amylase activity was high in the follicular phase but then decreased and was lowest when the phosphorylase activity was at its maximum. The amylase activity rose to a peak which coincided with that of $\mathrm{LH}$ and this was then followed by a decrease in the late lutel phase (Text-fig. 1).

No maltase activity could be detected in the cervical mucus.

The presence of carbohydrates in the cervical mucus has been reported by 
several authors (Breckenridge \& Pommerenke, 1951; Birnberg, Kurzrok \& Laafer, 1958). Recent studies by Kirton \& Hafs (1965) have indicated that glycogen-degrading enzymes are capable of capacitating rabbit spermatozoa in vitro. Glycogen degradation can be affected by (a) phosphorylysis by glycogen phosphorylase, (b) debranching by transferase and amylo-1,6-glycosidase, or (c) hydrolysis by amylase and maltase.

Amylase has been demonstrated in human cervical mucus and Fallopian tube tissue (Breckenridge \& Pommerenke, 1951; Green, 1957; McGeachin, Hargen, Potter \& Daus, 1958; Gregoire, Rankin, Johnson, Rakoff \& Adams, 1967). Skerlavay, Epstein \& Sobrero (1968) reported that amylase levels were relatively high in human cervical mucus during the pre- and postovulatory phases of the cycle. A secondary drop was observed in the amylase levels in some females during the mid-luteal phase, and coincided with the mid-luteal oestrogen surge. The fall in the levels of amylase in cervical mucus during the fertile period was thought to be due to the effect of oestrogen. Gregoire et al. (1967) reported that amylase levels were highest on Days 17 to 23 of the menstrual cycle. Administration of progestins resulted in a significant increase in the cervical amylase. Our findings concerning amylase levels in the cervical mucus of bonnet monkeys are very similar to those reported in women. Maximum amylase activity was encountered during the progestational phase of the cycle, followed by a significant decline during the late secretory phase.

These results support the observations of Skerlavay et al. (1968) and Gregoire et al. (1967) that amylase activity in cervical mucus is influenced by progesterone. Recently, MacDonald, Demers \& Greep (1973) have reported a correlation between peripheral serum progesterone and endometrial glycogen levels.

Fienberg \& Cohen (1968), using histochemical methods, reported the presence of glycogen phosphorylase in the squamous epithelium of the human cervix but no cyclic alterations were found in the distribution patterns of glycogen or glycogen metabolizing enzymes before and after ovulation. Our results demonstrate that glycogen phosphorylase activity in bonnet monkeys was higher in the follicular phase than in the luteal phase and a sharp decline in activity was observed following the LH peak. Ahrén \& co-authors (1973) have recently reported that LH enhances the glycogen phosphorylase activity in rat ovaries.

Our findings show that the pathway of glycogen metabolism in cervical mucus seems to alter during the menstrual cycle. In the follicular phase, both glycogen phosphorylase and amylase are involved in the degradation of glycogen but, during the luteal phase, glycogen is predominantly catabolized by amylase.

Studies are in progress to investigate the effect of contraceptive steroids on those enzymes in cervical mucus that are concerned with carbohydrate metabolism.

The standard reference preparation of ovine $\mathbf{L H}$ was kindly supplied by NIAMD, NIH, U.S.A. Highly purified ovine LH was obtained from Dr L. E. Reichert. 


\section{REFERENCES}

Ahrén, K., Hamberger, L., Herlttz, H., Hillensjo, T., Nilsson, L., Perklev, T. \& Selstam, G. (1973) Aspects of mechanism of action of gonadotropins. In The Endocrine Function of the Human Testis, Vol. I, pp. 251-262. Eds. V. H. T. James, N. Serio and L. Martini. Academic Press, New York.

Bernpizld, P. (1955), Amylase, $\alpha$ and $\beta$. In Methods in Enzymology, Vol. I, p. 149. Eds. S. P. Colowick and N. O. Kaplan. Academic Press, New York.

Birnberg, G. H., Kurzrok, R. \& LAAfER, A. (1958) Simple test for determining ovulation time. 7. Am. med. Ass. 166, 1174-1175.

Breckenridge, M. A. B. \& Pommerenke, W. T. (1951) Analysis of carbohydrates in human cervical mucus. Fert. Steril. 2, 29-44.

Demers, L. M., Gabee, S. G., Villee, G. A. \& Greep, R. O. (1972) The effect of insulin on human placental glycogenesis. Endocrinology, 91, 270-275.

Fienberg, R. \& Cohen, R. B. (1968) Enzymes of glycogen metabolism in the squamous epithelium of the cervix; a histochemical study. Am. 7. Obst. Gynec. 31, 608-616.

GreEN, C. L. (1957) Identification of $\alpha$-amylase as a secretion of human fallopian tube and tube-like epithelium of mullerian and mesonephric duct origin. Am. 7. Obst. Gynec. 73, 402-408.

Greenwood, F. G., Hunter, W. M. \& Glover, J. S. (1963) The preparation of ${ }^{131}$ I-labelled human growth hormone of high specific radioactivity. Biochem. 7. 89, 114-123.

Gregoire, A. T., RankIn, J., Johnson, W. O., Rakofr, A. E. \& Adams, B. S. (1967) $\alpha$-Amylase content in cervical mucus of females receiving sequential, non-sequential or no contraceptive therapy. Fert. Steril. 18, 836-839.

Kirton, K. T. \& HAFs, H. D. (1965) Sperm capacitation by uterine fluid or beta amylase in vitro. Science, N.Y. 150, 618-619.

MacDonald, G. J., Demers, L. M. \& Greep, R. O. (1973) Peripheral serum progesterone and correlated endometrial glycogen levels during the menstrual cycle of Macaca arctoides. Fert. Steril. 24, 98-103.

McGeachin, R. L., Hargan, L. A., Potter, B. A. \& Daus, A. T. (1958) Amylase in fallopian tubes. Proc. Soc. exp. Biol. Med. 99, 130-131.

Midgley, A. R., JR (1966) Radioimmunoassay: a method for human chorionic gonadotropin and human luteinizing hormone. Endocrinology, 79, 10-18.

Ovadia, J., McArthur, J. W., Kopito, L. \& Ulfelder, H. (1971) The cervical mucus secretion of the bonnet macaque (Macaca radiata). Biol. Reprod. 5, 127-145.

Sheth, A. R., Gunaca, K. P. \& RAo, S. S. (1970) Occurrence of amylo-1,6-glucosidase in human seminal plasma; its properties and significance in sperm metabolism. $\mathcal{F}$. Reprod. Fert. 22, 77-82.

Skerlavay, M., Epstein, J. A. \& Sobrero, A. J. (1968) Gervical mucus amylase levels in normal menstrual cycles. Fert. Steril. 19, 726-730. 